\title{
Contact with nature: effects of field trips on pro-environmental knowledge, intentions and attitudes
}

\author{
O contato com a natureza: efeitos de viagens ao campo sobre \\ os conhecimentos intenções e atitudes pró-ambientais
}

Zysman Neiman ${ }^{1}$. César Ades ${ }^{2}$

\begin{abstract}
The effects of direct contact with nature on pro-environmental attitudes, values and knowledge were assessed by taking college students on field trips at Parque Estadual Turístico do Alto Ribeira (PETAR), and applying a system of directed activities developed throughout 16 years. The changes in knowledge, values and attitudes were evaluated in these students (experimental groups) and other students who were not exposed to the field trips (control groups) through questionnaires which were applied before (pre-tests) and after the trip (post-tests). Meaningful differences were verified between the control and the experimental groups, as well as discrepancies between the pre- and post-tests applied to the experimental groups - a clear indication that the direct contact with nature affected the positioning of the students towards environmental matters. These outcomes reinforce the idea of the importance of contact with nature as a way of implementing pro-environmental behaviors.
\end{abstract}

Keywords: Environmental education. Field trip. Exposure to natural. PETAR.

Resumo: Os efeitos do contato direto com a natureza nos conhecimentos, nas intenções e atitudes pró-ambientais foram avaliados durante viagens com estudantes universitários ao Parque Estadual Turístico do Alto Ribeira (PETAR), onde foram realizadas atividades dirigidas desenvolvidas ao longo de 16 anos. As mudanças nos conhecimentos, valores e atitudes foram avaliadas nesses alunos (grupos experimentais) e em outros, que não participaram das viagens (grupos- controle), por meio de questionários que foram aplicados antes (pré-testes) e depois da viagem (pós-testes). Diferenças significativas foram verificadas entre os grupos-controle e experimentais, bem como discrepâncias entre os pré e pós-testes aplicados aos grupos experimentais - uma clara indicação de que o contato direto com a natureza afetou o posicionamento dos alunos em relação às questões ambientais. Estes resultados reforçam a ideia da importância do contato com a natureza como forma de implementar comportamentos pró-ambientais. Palavras-chave: Educação ambiental. Viagem a campo. Exposição ao natural. PETAR.

\footnotetext{
${ }^{1}$ Universidade Federal de São Paulo (UNIFESP), Rua Prof. Artur Riedel, 275, Jardim Eldorado, CEP 09972-270, Diadema, SP, Brasil. E-mail: <zneiman@gmail.com>

${ }^{2}$ Universidade de São Paulo (USP). † in memoriam.
} 


\section{Introduction}

It is increasingly acknowledged that human behavior may have an adverse influence on environmental conditions. Pollution, global warming, decrease in biodiversity, deforestation (especially in Brazil) and other critical issues are routinely conveyed through the media and constitute motives of environmental concern for an increasing amount of people around the world. (FRANZEN; MEYER, 2010; SCHULTZ et al., 2005).

In such a context of awareness of nature physical and biological degradation, it is essential to understand the factors that predispose people to interest themselves in environmental issues and also important to investigate reliable ways of stimulating pro-environmental values and behaviors (CINI; LEONE; PASSAFARO, 2012; CORRALIZA; BERENGUER, 2000; HERNANDEZ et al., 2000; JOHNSON; BOWKER; CORDELL, 2004; OREG; KATZ-GERRO, 2006; RICKINSON, 2001; SMITH-SEBASTO; CAVERN, 2006). Interest in promoting positive attitudes towards the environment through educational strategies is increasing in Brazil, a country with extensive natural areas and with a constant concern for conservation. (CARVALHO; SCHMIDT, 2008; CARVALHO; TOMAZELLO; OLIVEIRA, 2009; GUIMARÃES, 2004; JUNQUEIRA; NEIMAN, 2007; MENDONÇA; NEIMAN, 2003; PADUA, 2010; PADUA; JACOBSON, 1993; PEDRINI, 2006; SOARES, 2004; SENICIATO; CAVASSAN, 2004).

A special way of inducing a change in environmental attitudes is to provide a direct contact of students with nature through field trips. Field trips may stimulate the participants' curiosity, their sense of empathy for creatures, responsibility and unity with nature, maximizing the acquisition of information about nature and, ultimately, changing their conceptions about the importance of environmental conservation. (DIENNO; HILTON, 2005; FARMER; KNAPP; BENTON, 2007; HANNA, 1995; JACOBSON; PADUA, 1992; KNAPP; POFF, 2001; McKENZIE, 2000; NEGRA; MANNING, 1997; PALMBERG; KURU, 2000; RYAN, 1991).

The objective of our research was to evaluate the effects of guided contact with nature - through a field trip to a state natural park in São Paulo, Brazil - on college students' pro-environmental attitudes and behavioral intentions. Our experimental design, similar to the one used in Dimopoulos, Paraskevopoulos and Pantis (2008), included pre- and post-trip measures of knowledge, intentions and attitudes, so that effects of exposure to natural context could be assessed, in a repeated measures design, with the same participants. It also included control groups which were not exposed to the field trips from the same school and level of education, what allowed the scores were compared with those who had the exposure to the field trips.

\section{Method}

\section{Participants}

Participants were all college students, 17 to 25 years old, from a pedagogy course of the city of São Paulo $(n=52)$ and from a tourism course of the city of Sorocaba $(n=60)$. The number of male and female participants was practically equal in both the pedagogy $(51,9 \%$ female; 48,1\% male) and the tourism sample (51,7\% female; $49,3 \%$ male). Students accepted to participate in the study on a voluntary basis. 


\section{Procedure}

Pedagogy and tourism classes were assigned to experimental and control groups (pedagogy experimental, $\mathrm{n}=27$; pedagogy control, $\mathrm{n}=25$; tourism experimental, $\mathrm{n}=31$; tourism control, $n=29$ ), each with approximately the same number of female and male participants. Participants in all groups filled up the same questionnaires at the same period, at the beginning and at the end of the experiment (pre-trip and post-trip tests); participants in the experimental groups were however the only ones that took part in the field trip. As 6 of the participants did not fill up the post test forms, they were not included in the pre/post-trip comparisons.

Ecological trips were carried out at the Parque Estadual Turístico do Alto Ribeira (PETAR) - Touristic State Park of Alto Ribeira -, located in one of the last remaining regions of preserved Atlantic Forest of the State of São Paulo, with the highest concentration of natural caves.

Visiting and guiding procedures were those developed by the first author during a sixteen-year program of trips with students to the PETAR (more than a hundred visits from 1991 to 2007). The main objective of such trips was to draw participants' attention to relevant aspects of the natural and social environment through determined activities. Under the supervision of guides, they went through trails and galleries, followed underground rivers, exposed themselves to the darkness of the caves, detected and described the animals found. All activities were performed in a cooperative and playful way. They were also given information about the main environmental and cultural characteristics of the PETAR and surrounding region and were stimulated to interact with people from the local community. It was expected that they could thus obtain integrated knowledge about the history and present natural and social characteristics of the region. A special emphasis was put on the participants' sensory and emotional experience in contact with the environment.

After a two-day period of contact with the natural caves of PETAR, participants were taken to another state park, the Parque Estadual Jacupiranga, where they could visit the cave "Caverna do Diabo" (Devil's Cave), an artificially illuminated cave with stairways and paths built to facilitate mass tourism. Participants were encouraged to compare the feelings and impressions they got at the natural caves of PETAR and at the highly transformed "Caverna do Diabo" and to discuss the theme of distance between human and the nature.

\section{Questionnaires}

Self-evaluated knowledge questionnaire. Participants were asked to evaluate the knowledge they had about the Atlantic forest, natural environment, caves, conservation areas, environmental education and traditional communities (Table 1) by marking a point on visual analogue scales (NORRIS, 1971) which included $10 \mathrm{~cm}$ straight lines, the left starting point of which represented absolute ignorance of the subject while the right ending point, in-depth knowledge. The distance between the left starting point and the point participants marked was taken as an indication of the amount of self-evaluated knowledge. Internal consistency of this questionnaire was high (Cronbach's alpha $=0.853)$.

Pro-enviromental intentions questionnaire. In this questionnaire, participants were asked to evaluate how disposed they were to behave according to each of a list of pro-environmental conducts (participate of environmentalist movements, spread the need for environmental pres- 
ervation, affiliate to an environmentalist NGO, donate resources or work for environmental conservation, etc., Table 2).

Visual analogue scales were again used, with point zero on the straight lines representing total absence of wish and point 10 an utmost disposition. Internal consistency of the questionnaire was high (Cronbach's alpha $=0.896)$.

Attitudes questionnaire. Participants had to report their attitudes (opinions and feelings) about each of a list of topics on bipolar visual analog scales with extreme positions indicated on each side: what do you think about man's relationship to forest animals? (good/bad); What do you feel when you hear about animal and plant extinction? (I cannot do anything about it/I can do a lot); What do you think about wild animal hunt and trade? (I agree/I disagree); Do you agree with the following statement: "to ensure a species' preservation is to ensure the forest's preservation?" (I agree/I disagree), etc. (Table 3).

The middle point of the visual analog scale indicated a neutral position, the distance of the mark to either of the two alternatives was taken to indicate the degree of approval of this alternative. The internal consistency of the questionnaire was high (Cronbach's alpha $=0.847$ ).

\section{Results}

As Shapiro-Wilk's and Kolmororov-Smirnov's normality tests indicated that scores in most cases did not follow an approximately normal distribution $(p>0.05)$, we decided to use non-parametric statistical analyses. Mann-Whitney tests were used to compare experimental x control scores and Wicoxon tests to compare pre-trip to post-trip conditions.

Pedagogy $\times$ tourism. Scores of participants from the pedagogy course did not differ from scores of participants from the tourism course in practically all items of the three questionnaires, both under control and experimental conditions and in pre-trip and post-trip tests.

Selfevaluated knowledge about the environment. Scores of control and experimental groups did not differ significantly in the pre-trip test, either in tourism or pedagogy samples (Table 1), an indication that there were no differences in self-assessed knowledge prior to experimental treatment. Control x experimental significant increases appeared in the post-trip condition (tourism: items 1, 3, 5, 6; pedagogy: items 1, 2, 3, 4, 5 and 6, Table 1).

Table 1. Self-evaluated knowledge questionnaire

\begin{tabular}{|c|c|c|c|c|c|c|c|c|}
\hline \multirow{3}{*}{ Items } & \multicolumn{4}{|c|}{ Control x Experimental } & \multicolumn{4}{|c|}{ Pretrip x Posttrip } \\
\hline & \multicolumn{2}{|c|}{ Tourism } & \multicolumn{2}{|c|}{ Pedagogy } & \multicolumn{2}{|c|}{ Tourism } & \multicolumn{2}{|c|}{ Pedagogy } \\
\hline & pre & post & pre & post & Control & Experimental & Control & Experimental \\
\hline 1. Atlantic Forest & .864 & .049 & .800 & .014 & .883 & .004 & .745 & .039 \\
\hline 2. Environment & .558 & .992 & .271 & .016 & .239 & .101 & .464 & .005 \\
\hline 3. Caves & .204 & .001 & .165 & .001 & .324 & .000 & .159 & .000 \\
\hline 4. Conservation Areas & .367 & .132 & .396 & .035 & .318 & .015 & .321 & .035 \\
\hline 5. Environmental Education & .530 & .048 & .826 & .018 & .219 & .136 & 322 & .023 \\
\hline 6. Traditional Communities & .577 & .002 & .446 & .003 & .175 & .002 & .511 & .008 \\
\hline
\end{tabular}

P-value of Mann-Whitney's tests for control x experimental comparisons and Wilcoxon's tests for pre-trip x post-trip comparisons (significant results in boldface).

Source: Authors' data. 
Pre-trip x post-trip differences were significant for all items in pedagogy, and for 4 out of 6 items in tourism experimental groups (items 1, 3, 4, 6, Table 1).

Proenvironmental intentions. There were some significant differences between control and experimental groups in the pre-trip condition: tourism (items 1, 12, 14 and 15), and pedagogy (items 1, 9 and 12, Table 2). Differences between control and experimental groups occurred in most items in the post-trip testing: tourism (items 1, 2, 3, 4, 5, 6, 8, 10,11, 12, 13, 14, 15, and 16, Table 2); pedagogy (1, 2, 3, 4, 5, 6, 8, 9, 10, 11, 12, 13, 14, 15 and 16, Table 2), all differences indicating higher scores for experimental groups.

Significant pre-trip/post-trip differences, in control groups, were found in a few items, indicating changes that may not depend on trip experience. Significant pre-trip/post-trip increases in behavioral intentions occurred, in contrast, in all items, for both tourism and pedagogy experimental groups (Table 2).

Proenvironmental attitudes. There were some significant differences between control and experimental groups in the pre-trip testing: tourism (items 1, and 5), and pedagogy (items 5,

Table 2. Proenvironmental intentions questionnaire

\begin{tabular}{|c|c|c|c|c|c|c|c|c|}
\hline \multirow{3}{*}{ Proenvironmental intentions } & \multicolumn{4}{|c|}{ Control x Experimental $(p)$} & \multicolumn{4}{|c|}{ Post $\mathbf{x}$ Pre $(p)$} \\
\hline & \multicolumn{2}{|c|}{ TC } & \multicolumn{2}{|c|}{ PC } & \multicolumn{2}{|r|}{ TC } & \multicolumn{2}{|r|}{$\mathrm{PC}$} \\
\hline & pre & post & pre & post & Control & Experimental & Control & Experimental \\
\hline $\begin{array}{l}\text { 1. Take part in the } \\
\text { environmentalist movement }\end{array}$ & .016 & .026 & .042 & .008 & .627 & .000 & .534 & .004 \\
\hline $\begin{array}{l}\text { 2. Change their consumption } \\
\text { habits }\end{array}$ & .646 & .012 & .928 & .009 & .411 & .001 & .675 & .012 \\
\hline 3. Visit natural areas & .626 & .000 & .461 & .000 & .021 & .000 & .244 & .000 \\
\hline 4. Use the car less & .406 & .036 & .441 & .032 & .195 & .007 & .437 & .050 \\
\hline $\begin{array}{l}\text { 5. Disseminate environmental } \\
\text { preservation }\end{array}$ & .090 & .001 & .064 & .000 & .018 & .000 & .017 & .015 \\
\hline $\begin{array}{l}\text { 6. Take courses on the } \\
\text { environmental area }\end{array}$ & .148 & .012 & .090 & .006 & .786 & .000 & .550 & .003 \\
\hline $\begin{array}{l}\text { 7. Research and write articles } \\
\text { about the environment }\end{array}$ & .109 & .105 & .088 & .083 & .302 & .000 & .566 & .022 \\
\hline $\begin{array}{l}\text { 8. Reconsider their daily habits } \\
\text { to save resources }\end{array}$ & .734 & .001 & .948 & .001 & .026 & .032 & .098 & .050 \\
\hline $\begin{array}{l}\text { 9. Read or watch } \\
\text { documentaries about the } \\
\text { environment }\end{array}$ & .059 & .050 & .030 & .016 & .072 & .044 & .039 & .036 \\
\hline $\begin{array}{l}\text { 10. Be more integrated with } \\
\text { other people }\end{array}$ & .060 & .000 & .097 & .000 & .024 & .000 & .351 & .002 \\
\hline 11. Become more spiritualized & .708 & .048 & .639 & .027 & .627 & .002 & .886 & .019 \\
\hline $\begin{array}{l}\text { 12. Take care of plants and } \\
\text { animals }\end{array}$ & .044 & .079 & .044 & .016 & .984 & .000 & .848 & .014 \\
\hline 13. Recycle the trash & .334 & .000 & .319 & .000 & .805 & .000 & .028 & .000 \\
\hline $\begin{array}{l}\text { 14. Affiliate to an } \\
\text { environmentalist NGO }\end{array}$ & .028 & .017 & .059 & .004 & .740 & .000 & .649 & .000 \\
\hline $\begin{array}{l}\text { 15. Donate resources or work } \\
\text { voluntarily for Environmental } \\
\text { Conservation }\end{array}$ & .020 & .002 & .077 & .000 & .356 & .000 & .574 & .001 \\
\hline $\begin{array}{l}\text { 16. Pay more taxes. as } \\
\text { long as they are destined to } \\
\text { Environmental Conservation }\end{array}$ & .425 & .010 & .211 & .040 & .363 & .000 & .282 & .022 \\
\hline
\end{tabular}

P-value of Mann-Whitney's tests for control $x$ experimental comparisons and Wilcoxon's tests for pre-trip x post-trip comparisons (significant results in boldface).

Source: Authors' data. 
Neiman, Z.; Ades, C.

10 and 12). In the post-trip tests, control x experimental differences were all significant except for item 13, both for tourism and pedagogy groups (Table 3).

Table 3. Attitude questionnaire

\begin{tabular}{|c|c|c|c|c|c|c|c|c|}
\hline \multirow{3}{*}{$\begin{array}{c}\text { Attitudes } \\
\text { (opinions and feelings) }\end{array}$} & \multicolumn{4}{|c|}{ Control x Experimental $(p)$} & \multicolumn{4}{|c|}{ Post $\mathbf{x}$ Pre $(p)$} \\
\hline & \multicolumn{2}{|c|}{$\mathrm{TC}$} & \multicolumn{2}{|c|}{ PC } & \multicolumn{2}{|r|}{$\mathrm{TC}$} & \multicolumn{2}{|c|}{ PC } \\
\hline & pre & post & pre & post & Control & Experimental & Control & Experimental \\
\hline $\begin{array}{l}\text { 1. What do you think about the } \\
\text { relationship between forest } \\
\text { animals and man? (bad/good) }\end{array}$ & .042 & .000 & .094 & .001 & .272 & .014 & .519 & .085 \\
\hline $\begin{array}{l}\text { 2. What do you feel when } \\
\text { you hear about animal and } \\
\text { plant extinction? (I cannot do } \\
\text { anything/l can do a lot) }\end{array}$ & .521 & .023 & .651 & .005 & .618 & .001 & .310 & .139 \\
\hline $\begin{array}{l}\text { 3. How do you feel when you } \\
\text { enter the forest? } \\
\text { (afraid / very excited) }\end{array}$ & .798 & .000 & .561 & .000 & .995 & .000 & .976 & .000 \\
\hline $\begin{array}{l}\text { 4. How do you feel about wild } \\
\text { animal hunt and trade? (I agree } \\
\text { / I disagree) }\end{array}$ & .078 & .000 & .073 & .000 & .137 & .000 & .436 & .000 \\
\hline $\begin{array}{l}\text { 5. How do you feel when you } \\
\text { see forest areas burning? } \\
\text { (Happy/ sad) }\end{array}$ & .033 & .000 & .012 & .000 & .001 & .000 & .105 & .000 \\
\hline $\begin{array}{l}\text { 6. Do you agree with the } \\
\text { statement "Ensuring a species' } \\
\text { preservation is to ensure the } \\
\text { forest's preservation"? (I agree / } \\
\text { I disagree) }\end{array}$ & .206 & .001 & .353 & .000 & .418 & .001 & .430 & .000 \\
\hline $\begin{array}{l}\text { 7. How do you feel when you } \\
\text { enter a limestone cave? (afraid } \\
\text { / very excited) }\end{array}$ & .262 & .000 & .140 & .000 & .686 & .000 & .640 & .000 \\
\hline $\begin{array}{l}\text { 8. Do you agree with the } \\
\text { statement "the way of life of } \\
\text { traditional populations must } \\
\text { be maintained"? (I disagree / I } \\
\text { agree) }\end{array}$ & .099 & .000 & .840 & .000 & .255 & .000 & .503 & .000 \\
\hline $\begin{array}{l}\text { 9. Visiting natural areas } \\
\text { is disturbing or pleasant? } \\
\text { (disturbing/pleasant) }\end{array}$ & .119 & .000 & .061 & .000 & .008 & .000 & .929 & .000 \\
\hline $\begin{array}{l}\text { 10. Do you agree with the } \\
\text { statement "the Atlantic Forest } \\
\text { preservation is urgent"? (it's not } \\
\text { urgent/ it's urgent) }\end{array}$ & .053 & .000 & .022 & .000 & .011 & .000 & .243 & .000 \\
\hline $\begin{array}{l}\text { 11. When I am in direct contact } \\
\text { with Nature I feel: (isolated/ } \\
\text { integrated)? }\end{array}$ & .292 & .000 & .073 & .000 & .004 & .000 & .134 & .000 \\
\hline $\begin{array}{l}\text { 12. Do you agree with the } \\
\text { statement "nature teaches the } \\
\text { human being how to live"? (I } \\
\text { disagree/l agree) }\end{array}$ & .095 & .001 & .027 & .000 & .946 & .000 & .278 & .000 \\
\hline $\begin{array}{l}\text { 13. Do you agree with } \\
\text { the statement "the } \\
\text { environmentalists should think } \\
\text { more about the development of } \\
\text { society"? (I disagree / I agree) }\end{array}$ & .986 & .079 & .608 & .079 & .620 & .009 & .530 & .044 \\
\hline
\end{tabular}

P-value of Mann-Whitney's tests for control x experimental comparisons and Wilcoxon's tests for pre-trip x post-trip comparisons (significant results in boldface).

Source: Authors' data. 
Pre- x post-trip differences were found in control groups (tourism: items 5, 9, 10, 11). They were present in the experimental groups of tourism (all items, Table 3) and pedagogy (items 3, 4, 5, 6, 7, 8, 9, 10, 11, 12 and 13, Table 3), all differences indicating higher scores for this groups.

\section{Discussion}

The lineation of a research which is characterized by pre-test and post-test controls nearly all threats to the internal validity of a study. The separation of students in control or experimental group also avoids possibilities of experimental error. This design offers the same chance to both groups and exposes them to the same risks (PADUA, 1994). In this case, participating students in the Experimental Groups chose to take part in the trip, as it was constituent of the regular activities of their graduation program. As their participation would be at their own expenses, many of the students who were motivated to join could not do so and therefore composed the Control Group. Others, even though not interested in the destination of the trip, took part in it as, besides having financial conditions, would like to accompany their classmates. Therefore, it is not reckless to state that the distribution of the students within the groups did not happen in such a way to benefit a more "highly motivated" group of students in terms of carrying out the visits to the park in the Experimental Group as opposed to a "poorly motivated" team in the other group. Random allocation (through raffle or similar) was not possible due to the financial aspect involved. Another concern was to choose, within the 107 trips, two in which the students were linked to the human science courses (tourism and pedagogy), so that personal motivations of students of other areas (biology, geology, agronomy, forestall engineering, environmental management) would be minimized.

By addressing the external validity, that is, the possibility of generalization to other realities of the outcomes, it can be stated that, at least in the 107 trips, the profile of the public did not differentiate much from that observed in the Environmental Education and Ecotourism activities, which makes it reasonable to believe that, with respect to publics of the same social, economic and educational level, the results may be similar. Therefore, there can be an inference of the data obtained in this study to other populations whose realities are similar. Padua (1994) points out that the pre-test may influence the results, as it draws attention to determined topics which will again be asked, as well as it warns the interviewees on likely desirable responses, in case they know the objectives of the research. To minimize the influence, participants were not informed, in the moment of the pre-test, of the objectives of the research, nor were they induced on the relation between the test and the trip that would be carried out - what happened after the post-test only.

The efficiency of the field activities in the content learning had already been demonstrated by Bogner (1998). Hamilton-Ekeke (2007) compared the effectiveness of two teaching methods (field trip and expository methods of teaching) on students' performance in a concept in the ecology, also used as a strategy and analysis through pre- and post-tests. Similarly to the results here presented in respect to the acquisition of knowledge, the author found a meaningful difference between the pre- and post-tests taken by students who made the field trip, although the same difference was not found in the students who were exposed to a more 
deductive approach in teaching.

Thapa (2010) investigated recreationists' environmental attitude-behavior relationship and the impact of outdoor recreation activity orientation (as a mediator variable) on attitude-behavior correspondence. Overall, attitudes exhibited stronger direct relationships with behaviors, when compared to the effect of participation on behaviors. The influence of the participation in the activity on attitude-behavior correspondence was not significantly demonstrative. The author concludes that the association between participation in outdoor recreation and environmentalism is complex, and there is a need for additional research to better understand the relationship.

In this present study, however, the outcomes taken as a whole indicate that the practice of field trips, such as the ones accomplished at PETAR, has immediate significant effects upon a self-evaluated knowledge about the environment, pro-environmental intentions and attitudes towards the environment. The importance of these activities in the transformation in a pro-environmental way was detected statistically, showing differences within each group (pre $\mathrm{x}$ post) as well as within each experimental group compared to the control groups. One could ask if their attitudes and intentions actually changed or if they just had a better sense of what the 'right' answer was (i.e., what the tester/program was looking for), however the comparison with the control group has exactly the function to eliminate this uncertainty. There were similar results in two groups (tourism and pedagogy), without differences that could be related to the specialization field.

The results do not give an idea on how much the contact with the nature would be more or less efficient than other different shapes of Environmental Education. They are similar, however, to the studies carried out by Palmberg and Kuru (2000) which demonstrated, by means of questionnaires applied to 11-12 year-old children who were submitted to continuous outdoor education during several years, that these activities provide a means for students to interact, understand, and appreciate the need for conservation; increased awareness of environmental issues and actions contribute to increased motivation to take action.

It is also unknown how long the changes in pro-environmental attitudes and values endure. Effects of the field trip were tested immediately afterwards, so that experimental bias and communication between groups could be avoided. It would be interesting to plan other studies to verify, on one hand, the duration of effects of the contact with nature and, on the other hand, its influence on the concrete pro-environmental behavior of the students. However, we believe that this visit leaves a mark in any case. Our experience with groups shows that the individuals remember and keep the changes of attitude for a long time after the field trip.

The present study has used the directed contact with caves located in the Atlantic Forest as its essential point. It would be advisable to check similar (or different) effects in field trips made in other environments or ecosystems. An issue that requires investigation is how much the strategies of presentation and organization of the field trips in the visited environment should be changed.

Kollmuss and Agyeman (2011), claim that although many hundreds of studies have been undertaken, no definitive explanation has yet been found to explain the gap between the possession of environmental knowledge and environmental awareness, and displaying pro-environmental behavior. The evidences of the relationship between knowledge and behavior are still unfinished (CHAN, 1999; MARTIN; SIMINTRAS, 1995). While some studies seem to suggest that a higher level of knowledge results in effective pro-environmental behaviors 
(DIMOPOULOS; PARASKEVOPOULOS; PANTIS, 2008; PE’ER.; GOLDMAN; YAVETZ, 2007; SCHAHN; HOLZER, 1990), other authors state that this relationship is weak. (DISPOTO, 1977).

It is not easy to separate the cognition from the affection in the method and in its repercussions in the participants. But we believe that the creation of affective bonds with the environment, through a personal participation as well as personal and team experiences, such as the ones that occurred in the method utilized here, are prior to the establishment of the change. There are various indications that the cognitive aspect of the Environmental Education does not disconnect from the aspects of affective reaction. Zimmermann (1996) reviewed the studies on the relationship between knowledge, its effects and Environmental Education for 15 years (1979-1993) and suggests that there is an association between knowledge and feelings, as well as a significant difference between genders and an indication of ethnic variation. Li (1997) showed that feelings towards the environment are substantially related to affective behaviors and that knowledge does not seem to be an antecessor of emotions.

Finger (1994) had also demonstrated that the experiences with the nature are powerful instigators of pro-environmental behaviors, showing that these experiences are still more important than the explanation on their functioning. In this manner, the emotional affinity with the nature may be different from the cognitive interest in its parts, or from the curiosity on the flora, fauna, and the variety of its phenomena and natural processes. Some individuals might have scientific interest in the nature without feeling any emotional affinity with it. The emotional affinity is motivated through the contact and sensorial experiences. (KALS; SCHUMACHER; MONTADA, 1999). These emotional bonds, together with cognitive interests provided by leisure activities in the nature, increase the pro-environmental behavior. (VINING, 1992).

Reis and Roth (2009), by means of two ethnographic case studies to investigate the rhetorical and situational use of emotion discursive categories in interviews and authentic Environmental Education learning situations, suggest that rather than just being an outcome of effective instructional models designed to instill an environmental consciousness in students, emotion discourses are means to help account for and concretely realize the pedagogy of Environmental Education. Bogner (1998) evaluated how environmental education can promote pro-environmental behaviors in the long term, and generate attitudes about nature conservation and increase of basic ecological knowledge in students. As Kals, Schumacher and Montada (1999), and from the results obtained here, we believe that the direct experiences with the nature promote an emotional affinity and are efficient to the raise of changes of values and attitudes

An educational approach, like this one, will certainly have an outstanding contribution to the politics - which is in debate today - related to the environment. The political measures rely on the civil society and on the individuals. The organization of programs of visits to the environment must be enlarged because it makes changes in behavior easier and because it generates and supports initiatives of environmental protection and conservation. (WELLS; BRANDON, 1992).

The practice of Environmental Education in preserved areas that emphasize simply the "adventure" or prioritize the mere transmission of information of biological aspects (fauna and flora) offers few opportunities for reflection and contemplation, and must be substituted for others that allow more situations of affective interaction with the nature. In this study, some activities which were used (turn off the light in the caves and remain silent for some minutes, 
walk for some meters in total darkness, swim in rivers and waterfalls, try to listen to birds singing in the forest etc.) were efficient in the transformation of values and attitudes, as well as in the acquisition of knowledge.

Kollmuss and Agyeman (2011), claim that the biggest positive influence on pro-environmental behavior is achieved when internal and external factors act synergistically, but there possible barriers to positive influence on pro-environmental behavior, that must be overcome for it to manifest. We believe that many are the paths that lead to the expected ideal of comprehension and pro-environmental awareness. Within these paths, the contact with nature deserves a special attention due to its importance and its behavioral effects.

The social construction of a discourse and of an ideal of a "balanced environment" is fundamental to the creation of wanted pro-environmental behaviors. The symbolic thought and, sometimes, the mythological one, also hold great importance in this process, once they are the base to the creation of social representations towards the environment. The Environmental Education has, therefore, a broad scope in terms of reflection and action when it opens to non-rational dimensions of the human being, understanding perception as a phenomenon of existence. Students from both courses of pedagogy and tourism have undergone a complex experience in respect to perception. After all, besides having left their houses, they visited a touristic place of great natural beauty, lived common activities with their groups of friends, got in contact with local inhabitants, heard what their teachers said, etc. It can then be questioned which of these life experiences made the individual more sensitive to environmental questions.

The environmental sensitivity seems to be one of the main prerequisites towards a pro-environmental behavior. In other words, environmental sensitive people, affectionate to nature, are in a more favorable condition to the development of their environmental citizenship, or possess a necessary predisposition to the learning towards environmental issues. (HUNGERFORD; VOLK, 1990). The environmental sensitivity is the entrance door to an ecologically sound way of life. It is from the sensibility that the strength of our actions comes. What provokes resentment shows us what we are sensible to. So, if we seek environmental citizenship, we have to consider an education that allows the development of such sensitivity.

Not only with the purpose of trying to define operationally the environmental sensitivity as a psychological construct, recent studies in "Significative Life Experience" (SLE) attempted to identify the life experiences that appear to contribute regularly to the creation of environmental sensitivity. (SWARD; MARCINKOWSKI, 1998). Such studies are carried out based on autobiographical reports of leadership in the environmental field and reveal regularity in such reported experiences as rich in the creation of the environmental citizenship, that is, creators of individuals committed to environmental causes. The meaning of an experience depends much on the social-historical context the person is inserted in. That is to say we cannot force the environmental sensitization and it does not matter what activity is being proposed, as we can never be certain that those activities are, as a matter of fact, reaching the student. (SOARES, 2004).

In an autobiographical report-based study involving approximately 30 researchers of 12 different countries - of which 9 have already published their results - (PALMER et al., 1998), the positive experiences lived during childhood with nature, such as fishing, hunting, tree climbing or negative experiences which provoked feelings of loss or apprehension, such as bloodshed of fish, loss of green areas such as forests or woods, deaths of animals, lead the percentage as the main factors of the education of an active and committed environmental-driven 
citizen. These researches meet the results obtained in the $2^{\text {nd }}$ and $3^{\text {rd }}$ studies of this paper. In the bibliographical revision on SLE researches carried out by Chawla (1998) it is clearly noticed that activities which are developed outdoors, especially those in untouched wilderness or natural exuberance, definitely contribute to the consolidation of the environmental sensitivity. In one of the revised researches, $78 \%$ of the interviewees identified the living in natural areas as a main factor of influence upon the decision of pursuing a career in Conservation Biology; in other two revised researches, more than $90 \%$ of the interviewees reported that outdoor activities (vacation with family, childhood games, camping, fishing and hunting) were of utmost importance in the creation of a pro-environmental attitude. (SOARES, 2004). Researches of this kind have presented the same recurrent pattern. Rarely do interviewees identify a leaflet or a catalogue designed by a public organ as a factor that has determined their pro-environmental choices, although in some cases there is mention to personalities (professors, writers), videos or non-governmental organizations.

Padua (1997, p. 35) claims that "[...] in a dynamics process, the external conditions can influence the attitude of people towards the environment. This is the starting point for the great value of exposing people to a natural environment, where there is an opportunity of learning and sensitization".

The direct contact with nature without the objective of rationalizing it can be a powerful tool for Environmental Education.

\section{References}

BOGNER, F. X. The influence of short-term outdoor education on long-term variables of environmental perspective. The Journal of Environmental Education, Philadelphia, v. 29, n. 4, p. 17-29, 1998.

CARVALHO, I. C. M.; SCHMIDT, L. A pesquisa em educação ambiental: uma análise dos trabalhos apresentados na ANPED, ANPPAS e EPEA de 2001 a 2006. Pesquisa em Educação Ambiental, Rio Claro, v. 3, n. 2, p. 1-20, 2008.

CARVALHO, L. M.; TOMAZELLO, M. G. C.; OLIVEIRA, H. T. Pesquisa em educação ambiental: panorama da produção brasileira e alguns de seus dilemas. Cadernos CEDES, Campinas, v. 29, p. 13-28, 2009.

CHAN, R. Environmental attitudes and behavior of consumers in China: survey findings and implications. Journal of International Consumer Marketing, Philadelphia, v. 11, n. 4, p. 25-52, 1999.

CHAWLA, L. Significant life experiences revisited: a review of research on sources of environmental sensitivity. The Journal of Environmental Education, Philadelphia, v. 29, n. 3, p. 11-21, 1998.

CINI, F.; LEONE, L.; PASSAFARO, P. Promoting ecotourism among young people: a segmentation strategy. Environment and Behavior, McLean, v. 44, n. 1, p. 87-106, 2012.

CORRALIZA, J. A.; BERENGUER, J. Environmental values, beliefs, and actions: a situational approach. Environment and Behavior, McLean, v. 32, n. 6, p. 832-848, 2000. 
DIENNO, C.; HILTON, S. High school students' knowledge, attitudes, and levels of enjoyment of an environmental education unit on nonnative plants. The Journal of Environmental Education, Philadelphia, v. 37, n. 1, p. 13-25, 2005.

DIMOPOULOS, D.; PARASKEVOPOULOS, S.; PANTIS, J. D. The cognitive and attitudinal effects of a conservation educational module on elementary school students. The Journal of Environmental Education, Philadelphia, v. 39, n. 3, p. 47-61, 2008.

DISPOTO, R. Interrelationships among measures of environmental activity, emotionality and knowledge. Educational and Psychological Measurement, Thousand Oaks, v. 37, n. 2, p. 451-459, 1977.

FARMER, J.; KNAPP, D.; BENTON, G. M. An elementary environmental education field trip: long term effects on ecological/environmental knowledge and attitude development. The Journal of Environmental Education, Philadelphia, v. 3, n. 3, p. 33-42, 2007.

FRANZEN, A.; MEYER, R. Environmental attitudes in cross-national perspective: a multilevel analysis of the ISSP 1993 and 2000. European Sociological Review, Oxford, v. 26, n. 2, p. 219-234, 2010.

FINGER, M. From knowledge to action?: exploring the relationships between environmental experiences, learning, and behavior. Journal of Social Issues, Hoboken, v. 50, n. 3, p. 141-160, 1994.

GUIMARÃES, S. T. L. Dimensões da percepção e interpretação de meio ambiente: vislumbres e sensibilidades das vivências na natureza. OLAM - Ciência \& Tecnologia, Rio Claro, v. 4, n. 1, p. 46-64, 2004.

HAMILTON-EKEKE, J. T. Relative effectiveness of expository and field trip methods of teaching on students' achievement in ecology. International Journal of Science Education, Abingdon, v. 29, n. 15, p. 1869-1889, 2007.

HANNA, G. Wilderness-related environmental outcomes of adventure and ecology education programming. The Journal of Environmental Education, Philadelphia, v. 27, n. 1, p. 21-32, 1995.

HERNÁNDEZ, B. et al. The study of environmental beliefs by facet analysis: research in the Canary Islands, Spain. Environment and Behavior, McLean, v. 32, n. 5, p. 612-636, 2000.

HUNGERFORD, H. R.; VOLK, T. Changing learner behavior through environmental education. The Journal of Environmental Education, Philadelphia, v. 21, n. 3, p. 8-21, 1990.

JACOBSON, S. K.; PÁDUA, S. M. Pupils and parks-environmental education in national parks of developing countries. Childhood Education, Philadelphia, v. 68, n. 5, p. 290-293, 1992.

JOHNSON, C.Y.; BOWKER, J. M.; CORDELL, H. K. Ethnic variation in environmental belief and behavior: an examination of the new ecological paradigm in a social psychological context.

Environment and Behavior, McLean, v. 36, n. 2, p. 157-186, 2004.

JUNQUEIRA, V.; NEIMAN, Z. Educação ambiental e conservação da biodiversidade: reflexões e experiências brasileiras. Barueri: Manole, 2007.

KALS, E.; SCHUMACHER, D.; MONTADA, L. Emotional affinity toward nature as a motivational basis to protect nature. Environment and Behavior, McLean, v. 31, n. 2, p.178-202, 1999.

KNAPP, D.; POFF, R. A qualitative analysis of the immediate and short-term impact of an environmental interpretative program. Environmental Education Research, Abingdon, v. 7, n. 1, p. 55-65, 2001. 
KOLLMUSS, A.; AGYEMAN, J. Mind the gap: why do people act environmentally and what are the barriers to pro-environmental behavior? Environmental Education Research, Abingdon, v. 8, n. 3, p. 239-260, 2010.

LI, L.Y. Effect of collectivist orientation and ecological attitude on actual environmental commitment: the moderating role of consumer demographics and product involvement. Journal of International Consumer Marketing, Philadelphia, v. 9, n. 4, 31-53, 1997.

MARTIN, B. E.; SIMINTRAS, A. The impact of green product lines on the environment: does what they knowaffect how they feel? Marketing Intelligence and Planning, Bingley, v. 13, n. 4, p. 16-23, 1995.

McKENZIE, M. D. How are adventure education program outcomes achieved?: a review of the literature. Australian Journal of Outdoor Education, Milton, v. 5, n. 1, p. 19-28, 2000.

MENDONÇA, R.; NEIMAN. Z. À sombra das árvores: transdisciplinaridade e educação ambiental em atividades extraclasse. São Paulo: Chronos, 2003.

NEGRA, C.; MANNING, R. E. Incorporating environmental behavior, ethics, and values into nonformal environmental education programs. The Journal of Environmental Education, Philadelphia, v. 28, n. 2, p. 10-21, 1997.

NORRIS, H. The action of sedatives on brain stem oculomotor systems in man.

Neuropharmacology, Oxford, v. 10, n. 2, p. 181-191, 1971.

OREG, S.; KATZ-GERRO, T. Predicting proenvironmental behavior cross-nationally: values, the theory of planned behavior, and value-belief-norm theory. Environment and Behavior, McLean, v. 38, n. 4, p. 462-483, 2006.

PADUA, S. M. Conservation awareness through an environmental education programme in the Atlantic Forest of Brazil. Environmental Conservation, Cambridge, UK, v. 21, n. 2, p. 145-151, 1994.

PADUA, S. M. Uma pesquisa em educação ambiental: a conservação do mico-leão-preto (Leontopithecus chrysopygus). In: VALLADARES-PADUA, C.; BODMER, R.; CULLEN JR., L. (Org.). Manejo e conservação de vida silvestre no Brasil. Brasília: CNPq: Sociedade Civil Mamirauá, 1997. p. 34-42.

PADUA, S. M. Primate conservation: integrating communities through environmental education programs. American Journal of Primatology, Hoboken, v. 72, n. 6, p. 450-453, 2010.

PADUA, S. M.; JACOBSON, S. K. A comprehensive approach to an environmental education program in Brazil. The Journal of Environmental Education, Philadelphia, v. 24, n. 4, p. 29-36, 1993.

PALMBERG, I. E.; KURU, J. Outdoor activities as a basis for environmental responsibility. The Journal of Environmental Education, Philadelphia, v. 31, n. 4, p. 32-36, 2000.

PALMER, J. A. et al. An overview of significant influences and formative experiences on the development of adults' environmental awareness in nine countries. Environmental Education Research, Abingdon, v. 4, n. 4, p. 445-464, 1998.

PEDRINI, A. G. Avaliação da educação ambiental no ecoturismo (com trilhas): uma proposta metodológica de qualidade conceitual. OLAM - Ciência e Tecnologia, Rio Claro, v. 7, n. 2, p. 83-106, 2006. 
PE'ER, S.; GOLDMAN, D.; YAVETZ, B. Environmental literacy in teacher training: attitudes, knowledge, and environmental behavior of beginning students. The Journal of Environmental Education, Philadelphia, v. 39, n. 1, p. 45-59, 2008.

REIS, G.; ROTH, W.M. A feeling for the environment: emotion talk in/for the pedagogy of public environmental education. The Journal of Environmental Education, Philadelphia, v. 41, n. 2 , p. 307-327, 2009.

RICKINSON, M. Learners and learning in environmental education: a critical review of the evidence. Environmental Education Research, Abingdon, v. 7, n. 3, p. 207-320, 2001.

RYAN, C. The effect of a conservation program on school children's attitudes toward the environment. The Journal of Environmental Education, Philadelphia, v. 22, n. 4, p. 30-35, 1991.

SCHAHN, J.; HOLZER, E. Studies of individual environmental concern: the role of knowledge, gender and background variables. Environment and Behavior, McLean, v. 22, n. 6, p. 767-786, 1990.

SCHULTZ, P. W. et al. Values and their relationships to environmental concern and conservation behavior. Journal of Cross-Cultural Psychology, Thousand Oaks, v. 36, n. 4, p. 457-475, 2005.

SENICIATO, T.; CAVASSAN, O. Aulas de campo em ambientes naturais e aprendizagem em ciências: um estudo com alunos do ensino fundamental. Ciência \& Educação, Bauru, v. 10, n. 1, p. 33-147, 2004.

SMITH-SEBASTO, N. J.; CAVERN, L. Effects of pre and posttrip activities associated with a residential environmental education experience on students' attitudes toward the environment. The Journal of Environmental Education, Philadelphia, v. 37, n. 4, p. 3-17, 2007.

SOARES, F. J. Caminhos para o desenvolvimento da sensibilidade ambiental: uma incursão sobre as evidências. Projeto: revista de educação, Porto Alegre, v. 6, n. 8, p. 5-9, 2004.

SWARD, L. L.; MARCINKOWSKI, T. Environmental sensitivity: a review of the research, 1980-1998. In: HUNGERFORD, H. R. et al. (Ed.). Essential readings in environmental education. New York: Stipes Publishing, 1998. p. 277-288.

THAPA, B. The mediation effect of outdoor recreation participation on environmental attitudebehavior correspondence. The Journal of Environmental Education, Philadelphia, v. 41, n. 3, p. 133-150, 2010.

VINING, J. Environmental emotions and decisions. Environment and Behavior, McLean, v. 24, n. 1, p. 3-34, 1992.

WELLS, M.; BRANDON, K. (Ed.). People and parks: linking protected areas with local communities. Washington: WWF: USAID, 1992.

ZIMMERMANN, L. K. Knowledge, affect, and the environment: 15 years of research (1979-1993).

The Journal of Environmental Education, Philadelphia, v. 27, n. 3, p. 41-44, 1996.

Artigo recebido em 27/08/13. Aceito em 14/05/14. 